\title{
Analisis Pola Asuh Otoriter Orang Tua Terhadap Perkembangan Moral Anak
}

\author{
Bahran Taib1, Dewi Mufidatul Ummah ${ }^{2}$, Yuliyanti Bun ${ }^{3}$ \\ Universitas Khairun Ternate \\ Fakultas Keguruan dan Ilmu Pendidikan \\ Jl. Bandara Sultan Baabullah Kota Ternate Utara, Kotak Pos 53 Ternate 977328 Telepon: \\ (0921) 3110905-Faksimili 0921-3110901
}

Email: taibbahar4685@gmail.com

\begin{abstract}
Abstrak: Pola asuh otoriter adalah bentuk pola asuh yang menekankan pada pengawasan orang tua agar anak tunduk dan patuh. Orang tua memiliki pola asuh otoriter bersikap pemaksa, keras dan kaku dimana orang tua akan membuat berbagai aturan yang harus di patuhi oleh anakanaknya tanpa mau tahu perasaan sang anak. Orang tua akan emosi dan marah jika anak melakukan hal yang tidak sesuai dengan yang diinginkan oleh orang tuanya. Pola asuh otoriter seringkali dianggap sebagai pola asuh yang bisa mengganggu perkembangan anak. Beberapa fakta penelitian menunjukkan hasil bahwa pola asuh otoriter bisa berdampak negatif terhadap perkembangan anak tetapi terdapat hasil penelitian bahwa pola asuh otoriter bisa memiliki dampak positif terhadap perkembangan moral anak. Pola asuh otoriter juga memberikan dampak positif pada perilaku anak jika aturan yang dibuat orang tua bersifat wajib dilaksanakan seperti sholat, anak akan rajin beribadah dan sopan serta taat kepada orang tua. Pola asuh otoriter juga berdampak negatif jika orang tua terlalu menekan anak sehingga menjadi keras kepala, susah diatur, serta tidak taat kepada orang tua, hal ini disebabkan karena anak merasa dibatasi kebebasannya, dipaksa dan menghukum anak jika salah sehingga anak melampiaskan perasaanperasaannya dengan bertindak sesuai keinginannya. Diharapkan orang tua bisa menerapkan pola asuh yang baik sesuai dengan kebutuhan anak agar perkembangan anak dapat berkembang dengan baik terutama pada aspek perkembangan moral anak.
\end{abstract}

Kata Kunci: Pola Asuh Otoriter, Perkembangan Moral

\begin{abstract}
Authoritarian Parenting is the kind of parenting that emphasize on parents rules in order that children become submissive and obedient. The authoritarian parenting is strict, hard and stuff which they have the strict rules must be followed by the children with no discussion or compromising. They will be emotional and angry if the children do not be obedient. This parenting is seen as disturbing children development. Some research fact showed the result of authoritarian parenting have negative impact on children but it have positive impact on children development. The parents must make the rule for the activities likes prays, polite, and obedient. The negative impact of authoritarian parenting if the parents strict the children and the children feel restricted, children have a difficult time managing their anger and are very resentful. The parents should use the better parenting based on children development particularly on moral development.
\end{abstract}

Keywords : Authoritarian Parenting, Moral Development

\section{A. Pendahuluan}

Berbicara tentang anak tidak terlepas dari orang tua. Anak adalah sebuah amanah yang diberikan Tuhan dan akan dipertangung jawabkan olehtempat titipnya amanah tersebut yaitu orang tua. Keluarga merupakan yang pertama dimana anak dapat berinteraksi. Sangat besar pengaruh keluarga dalam pembentukan dan pengembangan kepribadian anak. Salah satu faktor dalam keluarga yang memiliki peran dalam pembentukan dan perkembangan kepribadian anak adalah pola asuh yang di terapkan orang tua. Hal tersebut dikuatkan oleh pendapat Brown (1961: 76) 
yang mengatakan bahwa keluarga adalah lingkungan yang pertama kali menerima kehadiran anak.

Anak merupakan generasi penerus yang harus diberikan stimulasi yang sangat baik dalam tahapan pertumbuhan dan pekembangannya, dimana anak harus diberikan pendidikan sejak usia dini untuk mengoptimalkan semua aspek perkembangan yang ada pada diri anak. Pendidikan anak usia dini (PAUD) adalah suatu upaya pembinaan yang ditunjukan kepada anak sejak lahir sampai dengan usia 6 (enam) tahun yang dilakukan melalui pemberian rangsangan pendidikan untuk membantu pertumbuhan dan perkembangan jasmani dan rohani agar anak memiliki kesiapan dalam memasuki pendidikan lebih lanjut (Permendikbud No 146, 2014: 3). Hal tersebut merupakan upaya strategi menyiapkan generasi bangsa yang berkualitas dalam rangka memasuki era globalisasi yang penuh dengan berbagai tantangan. Pendidikan Anak Usia Dini (PAUD) merupakan wahana pendidikan yang sangat fundamental dalam memberikan kerangka dasar terbentuknya dan berkembangnya dasar-dasar pengetahuan, sikap dan keterampilan anak (Wahyudin, 2012: 6). Namun dalam proses pendidikan usia dini, guru biasanya menemukan berbagai perilaku anak. Perilaku anak yang beragam sangatlah tergantung dari mana anak ini berasal.

Keluarga merupakan lingkungan pertama bagi seorang anak dalam mempelajari berbagai macam hal yang tidak pernah diketahuinya. Anak akan belajar untuk pertama kalinya melalui orang terdekatnya (orang tua). Ki Hajar Dewantara (Shochib, 1998: 10) menyatakan bahwa keluarga merupakan pusat pendidikan yang pertama dan terpenting, karena sejak timbulnya peradaban manusia sampai sekarang keluarga selalu mempengaruhi pertumbuhan budi pekerti tiap-tiap manusia. Lingkungan keluarga merupakan tempat dimana seorang anak berinteraksi untuk pertama kalinya. Dalam keluarga anak mendapat rangsangan dalam pertumbuhan maupun perkembangannya, baik biologis maupun psikologis. Dalam proses belajar inilah, seorang anak akan mencontohkan apa yang diajarkan dan dilakukan oleh setiap anggota keluarganya. Morisson (2016: 26) mengemukakan bahwa pembelajaran terjadi utamanya lewat modeling, observasi, keteladanan pengalaman dan peraturan diri dengan melewati empat tahapan, yaitu: 1) memperhatikan orang lain. 2) memilih perilaku-perilaku tertentu untuk diproduksi. 3) mengingat perilaku-perilaku yang diamati. 4) memproduksi ulang perilaku yang diamati. Hal ini merupakan momen penting dalam kehidupan anak ke depan.

Perilaku keluarga khususnya orang tua dalam menerapkan pola asuh terhadap anak akan berpengaruh pada proses tumbuh kembang anak terutama dalam membentuk kepribadian anak. Setiap orang tua mempunyai pola asuh tersendiri dalam mendidik anaknya, dan ini mempengaruhi perkembangan anak. Menurut Djamarah (2004: 67) mengungkapkan bahwa setiap orang tua tentunya ingin yang terbaik bagi anak-anak mereka, keingginan ini kemudian membentuk pola asuh yang di tanamkan orang tua kepada anak-anak. Orang tua diharapkan mampu menerapkan pola asuh yang sesuai pada anak dengan memberikan contoh yang baik serta dukungan kepada anak dalam mengembangkan bakat dan minat yang dimilikinya. Kepribadian anak akan menjadi baik atau tidak tergantung dari pola asuh yang diterapkan oleh orang tuanya. Damayanti (2019: 1) melakukan penelitian dan menyimpulkan bahwa ada pengaruh pola asuh orang tua terhadap perilaku sosial anak terbukti dengan melihat hasil pengamatan beberapa kategori pola asuh orang tua, dengan rata-rata kategori berkembang sesuai harapan.

\section{B. Pembahasan}




\section{Pengertian Pola Asuh}

Pola asuh terdiri dari dua kata yaitu pola dan asuh. Menurut Kamus Besar (KBBI) Bahasa Indonesia, pola berarti corak, model, sistem, cara kerja, bentuk (struktur) yang tetap. Sedangkan kata asuh dapat berarti menjaga (merawat dan mendidik) anak kecil, membimbing (membantu; melatih dan sebagainya), dan memimpin (mengeplai dan menyelenggarakan) satu badan atau lembaga (KBBI, 2008).

Shochib (1998: 14) mengatakan bahwa pola pertemuan antara orang tua sebagai pendidik dan anak sebagai terdidik dengan maksud bahwa orang tua mengarahkan anaknya sesuai tujuannya, yaitu membantu anak memiliki dan mengembangkan dasar-dasar disiplin dirinya. Orang tua dengan anaknya sebagai pribadi dan sebagai pendidik, dapat menyikapi pola asuh orang tua dalam disiplin diri anak yang tersirat dalam situasi dan kondisi yang bersangkutan.

Aisyah (2010) menyatakan pola asuh orang tua merupakan interaksi antara orang tua dengan anaknya selama mengadakan kegiatan pengasuhan. Dalam hal ini akan sangat berpengaruh pada individu anak terhadap perilaku dan juga diri anak sendiri baik positif maupun negatif. Disadari bahwa hampir tidak ada orang tua yang mempraktikkan pola asuh secara murni yang sesuai atau tidak sesuai dengan berbagai tipe pola asuh yang sering diterapkan oleh orang tua. Bahkan, orang tua ada yang melakukan pengasuhan kepada anaknya secara situasional.

Morrison (2016: 335) Pengasuhan anak adalah pengasuhan dan pendidikan anak-anak diluar rumah secara komperhensif untuk melengkapi pengasuhan dan pendidikan anak yang diterima dari keluarganya. Programprogram pengasuhan anak ditujukan untuk memenuhi beragam kebutuhan. Pola asuh orang tua adalah interaksi antara orang tua dengan anak memenuhi kebutuhan anak, mendidik, membimbing, menanamkan nilai-nilai kedisiplinan anak baik dalam tingkah laku serta pengetahuan agar tumbuh kembang anak berkembang secara optimal dengan penguatan yang diberikan orang tua.

\section{Pola Asuh Otoriter}

Pola asuh otoriter adalah pola asuh yang merupakan kebalikan dari pola asuh demokratis yaitu cenderung menetapkan standar yang mutlak harus dituruti, biasanya disertai dengan ancaman-ancaman. Bentuk pola asuh ini menekan pada pengawasan orang tua atau kontrol yang ditunjukan pada anak untuk mendapatkan kepatuhan ketaatan. Hal tersebut dikuatkan oleh Bumrind (dalam santrock 2002: 257-258) menurutnya pola asuh otoriter adalah suatu bentuk pola asuh yang menuntut agar anak patuh dan tunduk terhadap semua perintah dan aturan yang dibuat oleh orang tua tanpa ada kebebasan untuk bertanya atau mengemukakan pendapat sendiri. Anak di jadikan sebagai miniatur hidup dan pencapaian misi hidupnya. Hal ini sejalan dengan pendapat Shapiro (1992:27) bahwa "Orang tua otoriter berusaha menjalankan rumah tangga yang di dasarkan pada struktur dan tradisi, walaupun dalam banyak hal tekanan mereka akan keteraturan dan pengawasan membebani anak. Jadi orang tua yang otoriter sangat berkuasa terhadap anak, memegang kekuasaan tertinggi serta mengharuskan anak patuh pada perintah-perintahnya. Menurut Santrock (1998) pola asuh otoriter, yaitu pola asuh yang penuh pembatasan dan hukuman (kekerasan) dengan cara orang tua memaksakan kehendaknya, sehingga orang tua dengan pola asuh 
otoriter memegang kendali penuh dalam mengontrol anak-anaknya. Menurut Dariyo (2011: 207) menyebutkan bahwa "pola asuh otoriter adalah sentral artinya segala ucapan, perkataan, maupun kehendak orang tua dijadikan patokan (aturan) yang harus ditaati oleh anak-anaknny". Supaya taat, orang tua tidak segan-segan menerapkan hukuman yang keras kepada anak.

Pola asuh otoriter ini menjelaskan bahwa sikap orang tua yang cenderung memaksa anak untuk berbuat sesuatu sesuai dengan keinginan orang tua. Pola asuh ini adalah pola asuh dimana orang tua memberikan peraturan-peraturan kepada anaknya dan anak harus mematuhi peraturan yang dibuat dilingkungan keluarga. Hal tersebut di kuatkan oleh pendapat Hurlock (1980) menjelaskan bahwa penerapan pola asuh otoriter sebagai disiplin orang tua secara otoriter yang bersifat disiplin tradisional. Dalam disiplin yang otoriter orang tua menetapkan peratura-peraturan dan memberitahukan anak bahwa ia harus mematuhi peraturan tersebut. Anak tidak di berikan penjelasan mengapa harus patuh dan tidak diberi kesempatan mengemukakan pendapat meskipun peraturan yang ditetapkan tidak masuk akal.

a. Ciri-ciri pola asuh otoriter

1) Menurut Baumrind (dalam Syamsu Yusuf: 2005)

a) Orang tua suka menghukum secara fisik.

b) Orang tua cenderung bersikap mengomando (mengharuskan atau memerintah anak untuk melakukan sesuatu tanpa kompromi).

c) Bersikap kaku.

d) Orang tua cenderung emosional dan bersikap menolak.

b. Menurut Yamin dan Irwanto (dalam Yupit Yuliyanti 1991: 100)

1) Kurang komunikasi.

2) Sangat berkuasa.

3) Suka menghukum.

4) Selalu mengatur.

5) Suka memaksa.

6) Bersifat kaku.

c. Menurut Hurlock (dalam Ethes: 1993)

1) Anak dituntut untuk patuh kepada semua perintah dan kehendak orang tua.

2) Sering memberikan hukuman fisik kepada anak.

3) Jarang memberikan pujian dan hadiah apabila anak mencapai suatu prestasi.

4) Pengontrolan terhadap tingkah laku anak sangat ketat.

5) Kurang adanya komunikasi yang baik terhadap anak.

Bentuk pola asuh otoriter memiliki ciri-ciri orang tua bertindak tegas, suka menghukum, kurang memberikan kasih sayang, kurang simpatik, memaksa anak untuk patuh terhadap peraturan, dan cenderung mengekang keinginan anak. Selain itu pola asuh otoriter penerimaan (responsiveness) rendah dan tuntutan (demandingness) orang tua tinggi. Kecendurungan pola asuh otoriter menyebabkan anak kurang insiatif, menjadi tidak disiplin, cenderung ragu, dan mudah gugup. Anak laki-laki dengan pola asuh otoriter memiliki kemungkinan untuk berperilaku agresif. Odebunmi (2007, dalam Okorodudu, 2010) mengungkapkan bahwa hasil dari beberapa laporan penelitian yang 
telah dilakukan menunjukan sebagian besar dari semua kenakalan remaja berasal dari rumah yang orang tuanya kurang memiliki cinta dan perhatian. Perhatian, cinta dan kehangatan tidak ada dalam membantu perkembangan emosional dan penyesuaian pada anak. Rahayu dkk (2008).

Penelitian yang dilakukan di China justru menunjukkan fakta sebaliknya, yaitu pola asuh otoriter memberi dampak yang positif terhadap perkembangan anak. Chao (2001)mengatakan bahwa pola asuh otoriter berdampak negatif pada anak darikeluarga Eropa-Amerika namun pola asuh ini justru memberi dampak positif pada keluarga Cina- Amerika. Dalam artikelnya yang lain, Chao (1994, 2000) berkeyakinan bahwa pendekatan dari orang tua, terutama ibu, member dampak yang lebih positif terhadap perkembangan anak apabila di asuh dengan pola asuh otoriter. Inkonsistensi hasil penelitian terkait pola asuh otoriter ini menjadi dasar bahwa dibutuhkan variabel tertentu yang dapat menerangkan efek dari pola asuh otoriter terhadap perkembangan anak. Variabel ini akan dapat menjelaskan bahwa dampak negatif atau positif dari pola asuh otoriter tergantung kondisi variabel yang menjadi perantaranya. Variabel yang diharapkan menjadi variable moderator terkait pola asuh otoriter dan dampak pada perkembangan anak adalah kesabaran, hal ini mengacu pada penelitian pada remaja yang menunjukkan adanya peran kesabaran sebagai mediator dari pengaruh yang positif antara religiusitas dan kemampuan negosiasi konflik integratif (El Hafiz \& Nuramalina, 2015).

\section{Perkembangan Moral Anak}

Perkembangan dapat diartikan sebagai perubahan yang progresif dan kontinyu (berkesinambungan) dalam diri individu dari mulai lahir sampai mati, (The Progressive and continous change In the organism from birth to death). Pengertian lain dari perkembangan adalah "perubahan-perubahan yang dialami individu atau organisme menuju tingkat kedewasaannya atau kematangannya (Maturation) yang berlangsung secara sistematis, progresif dan berkesinambungan, baik menyangkut fisik (jasmani) maupun psikisis (rohaniah)". (Syamsu Yusuf 2007: 15).

Jadi secara umum bahwa perkembangan tidaklah terbatas pada pengertian pertumbuhan yang semakin membesar melainkan di dalamnya juga terkadang seringkali perubahan yang berlangsung secara terus menurus dan bersifat tetap dari fungsi-fungsi jasmani dan rohania yang dimiliki individu menuju ketahapan kematangan melalui pertumbuhan, pemasakan, dan belajar. (Desmita 2010: 8-9). Faktor-faktor yang mempengaruhi perkembangan adalah hereditas (keturunan atau pembawaan) dan lingkungan keluarganya. Faktor keturunan, karakter dan potensi yang dimiliki oleh seorang individu adalah warisan dari orang tuanya. Sedangkan faktor lingkungan, menurut J.P. Chaplin mengemukakan bahwa lingkungan merupakan keseluruhan aspek atau fenomena fisik dan sosial yang mempengaruhi organisme individu. (Syamsu Yusuf 2007: 35). Lingkungan individu yang dimaksud adalah mencakup lingkungan keluarga, sekolah, kelompok sebaya, dan masyarakat sekitar.

Sedangkan pengertian moral menurut Hurlock (1978: 74) ada beberapa istilah dalam perilaku moral, yaitu perilaku moral berarti perilaku yang sesuai dengan kode moral kelompok sosial. "moral" berasal dari kata latin mores, yang berarti tata cara, kebiasaan, dan adat. Perilaku moral dikendalikan konsep-konsep moral, peraturan perilaku yang telah menjadi kebiasaan bagi anggota suatu 
budaya dan yang menentukan pola perilaku yang diharapkan dari seluruh anggota kelompok. Ada dua tahapan perkembangan moral, yang pertama disebut "realism moral" atau "moralitas oleh pembatasan".Sedangkan tahapan yang ke dua disebut "tahap moralitas ekonomi" atau "moralitas oleh kerjasama atau hubungan timbal balik".

Dalam tahapan yang pertama, perilaku anak ditentukan pada peraturan perilaku yang spontan atau tidak disadari. Mereka mengangap bahwa orang tua dan orang dewasa adalah sebagai pemimpin dan anak hanya mengikuti peraturan yang diberikan tanpa mempertanyakan kebenarannya. Dalam tahap perkembangan moral ini anak menilai tindakan sebagai " benar" atau "salah" atas dasar konsekuensinya dan bukan berdasarkan motivasi dibelakangnya. Sedangkan tahap ke dua perkembangan moral, anak menilai perilaku atas dasar tujuan yang mendasarinya. Tahap ini biasanya dimulai antara usia 7-8 tahun dan berlanjut hingga usia 12 atau lebih. Atara usia 5-7 atau 8, konsep anak tentang keadilan mulai berubah. Konsep benar salah yang telah dipelajari dari orang tua secara bertahap dimodifikasi. Akibatnya, anak mulai mempertimbangkan suatu keadaan tertentu yang berkaitan dengan suatu pelangaran moral. Pola asuh otoriter orang tua sangat berpengaruh terhadap perkembangan moral anak. Pola otoriter dapat mengakibatkan anak anak kurang insiatif, menjadi tidak disiplin, cenderung ragu, dan mudah gugup. Pola pengasuhan anak adalah salah satu faktor yang sangat mempengaruhi bagaimana masa depan anak. Apakah iya tumbuh seperti dambaan orang tua atau bahkan sebaliknya. Maka faktor yang menjadi penyebab tidak tercapainya harapan orang tua terhadap anak, antara lain adalah ketidak tahuan orang tua tentang bagaimana mendidik atau mengasuh anak secara benar. Pola asuh yang benar adalah yang mengacu pada konsep dasar tumbuh kembang (asah, asih ,asuh) sehingga anak dapat tumbuh dan berkembang secara optimal.

Perkembangan moral adalah perubahan tingkah laku yang terjadi didalam kehidupan sehari-hari yang berkaitan dengan tata cara, adat, kebiasaan yang berlaku dilingkungan. Pola asuh sangat erat hubungannya dengan moral anak karena pola asuh orang tua adalah suatu interaksi antara ayah dan ibu kepada anak, dimana tujuan orang tua adalah membentuk perilaku, pengetahuan serta nilai moral yang dianggap baik oleh orang tua. Untuk mencapai harapan agar tingkah laku anak dapat diterima oleh masyarakat, orang tua tidak hanya memberikan peraturan yang harus di taati anak akan tetapi orang tua juga harus memberikan contoh yang baik dalam kehidupan bermasyarakat. Penanaman moral ini akan lebih berhasil, jika perbuatan yang benar disambut dengan respon yang menyenangkan, misalnya dengan pujian. Apabila orang tua dapat memberikan pola asuh yang tepat maka perkembangan moral anak akan berkembang sesuai harapan. Pola pengasuhan adalah asuhan yang diberikan ibu atau pengasuh lain berupa sikap, perilaku dalam hal kedekatannya dengan anak, memberikan kesempatan kepada anak, merawat, menjaga kebersihan, memberi kasih sayang, dan sebagainya (Septiari, 2012:162). Pola asuh ini satu faktor yang sangat mempengaruhi bagaimana pembentukan perilaku anak di masa depan. Apakah iya akan menjadi anak seperti harapan orang tua atau malah sebaliknya.

\section{Analisis Pola Asuh Otoriter Orang Tua Terhadap Perkembangan Moral Anak}

Matsumato (2004) menyebutkan bahwa orang tua berperan sangat penting dalam meletakkan dasar-dasar perilaku bagi anaknya. Sikap, perilaku dan 
tindakan serta kebiasaan orang tua selalu dilihat, dinilai, ditiru, dan diperhatikan oleh anak lalu semua itu secara sadar atau tidak sadar akan menjadi kebiasaan bagi anak-anaknya pula. Hal demikian disebabkan karena anak mengidentifikasikan diri pada orang tuanya sebelum mengidentifikasi orang lain. Dan dengan demikian maka konsep diri anak dapat terbentuk dimulai dari pengaruh orang tuanya, dimana anak masih berada dalam pengasuhan orang tua. Hubungan orang tua dan anak menjadi aspek yang sangat penting melalui tipe pengasuhan yang diterapkan oleh orang tua. Santrock (2011) mengemukakan bahwa anak- anak dari orang tua otoriter sering tidak bahagia, takut dan ingin membandingkan dirinya dengan orang lain, gagal untuk memulai aktivitas dan memiliki komunikasi yang lemah, berperilaku agresif. Yusuf (2006) bahwa sikap otoriter orang tua akan berpengaruh pada profil perilaku anak. Perilaku anak yang mendapat pengasuhan otoriter cenderung bersikap mudah tersinggung, penakut, pemurung, tidak bahagia, mudah terpengaruh, mudah stress, tidak mempunyai arah masa depan yang jelas dan tidak bersahabat.

Dan dari hasil penelitian Ni Putu Ayu Resitha Dewi dan Luh Kadek Pande Ary Susilawati dengan judul penelitian " Hubungan Antara Kecenderungan Pola Asuh Otoriter (Authoritarian Parenting Style) Dengan Gejala Perilaku Agresif Pada Remaja" dapat disimpulkan bahwa pengasuhan otoriter yang orang tua terapkan dalam pengasuhan anak seringkali menggunakan hukuman fisik sebagai bentuk konsekuensi yang harus di terima oleh anak ketika melanggar aturan dan standar yang sudah ditetapkan. Anak menganggap bahwa rumah adalah tempat dimana anak harus patuh akan standar orang tua, tempat dimana tidak adanya kesempatan untuk mengutarakan pendapat, dan rumah merupakan tempat resiko hukuman sangat besar diperoleh sehingga ketika berada di luar rumah, anak akan melakukan yang tidak bisa dilakukannya di rumah dan lebih cenderung memunculkan perilaku agresif (Taylor dkk, 2009).

Namun pola asuh otoriter yang diterapkan orang tua kepada anak dapat memberikan dampak positif bagi perilakunya, akibat dari keinginan orang tua yang harus dituruti tanpa pengecualian dari anak, terkadang timbul sebuah keinginan yang bersifat positif. Maka berdasarkan hasil observasi/pengamatan langsung di lapangan yang dilakukan oleh Juhardin, H. Jamaluddin Hos, dan $\mathrm{Hj}$. Suharty Roslan dengan judul penelitian "Dampak Pola Asuh Orang Tua Terhadap Perilaku Anak di Desa Amberi Kecamatan Lambuya Kabupaten Konawe" dengan jenis penelitian menggunakan data kualitatif yang diperoleh secara jelas dan menggambarkannya secara sistematis. Sumber data dalam penelitian ini terdiri atas data primer dan data sekunder. Data primer yaitu data yang diperoleh dari sejumlah informan penelitian melalui tahap wawancara, observasi, dokumentasi. Dan data sekunder yaitu data yang diperoleh tidak secara langsung dari informan penelitian seperti data mengenai karakteristik lokasi penelitian. Berdasarkan teori dan penelitian-penelitian sebelumnya yang relevan dapat disimpulkan bahwa jika anak dipaksa untuk melakukan sesuatu yang bersifat positif misalnya anak dipaksa untuk sholat maka dapat mempengaruhi perkembangan moral anak dan jika anak tidak melakukannya maka anak akan diberikan hukuman lain contoh lain seperti anak perempuan yang di perintahkan ayahnya untuk menghabiskan waktu lebih banyak di rumah dan membantu ibunya dari pada diluar rumah karena takut anaknya yang terjebak dalam kenakalan remaja.

Berdasarkan teori dan penelitian-penelitian sebelumnya yang relevan dapat disimpulkan bahwa analisis dari pola asuh otoriter yang di terapkan oleh 
orang tua dapat berpengaruh terhadap perkembangan moral anak baik dampak positif maupun dampak negatif. Dampak positif yaitu jika anak dipaksa melakukan sesuatu yang hukumnya wajib misalnya mengerjakan sholat, ibadah dan taat kepada orang tua maka akan berdampak positif terhadap moral, sedangkan dampak negatifnya yaitu jika anak diberi aturan yang banyak, ditekan, sering dibentak, dicaci maki, dan menuntut kepada anak makan akan berdampak negatif pada perilaku moral anak.

Di maluku utara terdapat beberapa kasus yang mengindikasikan kurang tepatnya pola asuh yang dilakukan oleh orang tua. Sedikitnya 21 pelajar dari berbagai sekolah di Ternate berhasil diamankan jajaran Satuan Polisi Pamong Praja (Satpol PP) Kota Ternate dalam sebuah operasi pelajar di sejumlah tempat (indotimur.com, Selasa 17/9/2019). Berdasarkan pra penelitian yang dilakukan oleh Situmorang, Ismail, dkk (2018) bahwa pra penelitian yang dilakukan menunjukkan bahwa presentasi siswa di SMA " $X$ " di ternate yang melakukan kenakalan remaja sekitar $60 \%$ dari 100\% siswa. Metode yang dilakukan adalah menggunakan metode wawancara dengan guru BK. Wawancara di lakukan pada siswa kelas X jurusan MIA berjumlah 6 orang diperolah informasi bahwa di sekolah sering terjadi tawuran setelah pulang sekolah yang sebagian besarnya adalah siswa laki-laki.

Siswa juga mengatakan bahwa pada saat sedang dalam proses belajar ada salah satu teman diantara mereka yang sering keluar masuk kelas tanpa meminta ijin terlebih dalu pada guru mata pelajaran. Perilaku kenakalan remaja memilki dampak yang negatif yakni akan menghambat dirinya dalam proses sosialisasi terutama dengan remaja lain, dengan guru di sekolah dan dengan masyrakat di lingkungannya. Selain itu semua pihak akan menanggung dampak negatif dari kenakalan remaja tidak hanya korban bahkan pelaku dan remaja yang melakukan kenakalan. Dengan menerapkan pola asuh yang tepat seperti pola asuh otoriter di usia dini diharapkan akan membantu anak mengoptimalkan perkembangan moralnya sehingga akan menggurangi timbulnya kasus kenakalan pada tahapan selanjutnya yaitu remaja.

\section{Kesimpulan}

Berdasarkan hasil analisis yang dilakukan penulis, dapat di simpulkan bahwa pola asuh otoriter orang tua sangat berpengaruh terhadap perkembangan moral anak. Pola asuh otoriter bisa berdanpak positif maupun negatif. Dampak negatif dimana jika anak tidak merasakan kebahagian dengan aturan yang di berikan orang tua anak menjadi keras kepala, menjadi tidak disiplin, cenderung ragu, mudah gugup, merasakan ketakutan, cemas, merasa minder jika di bandingkan dengan orang lain, tidak mampu memulai aktifitas, serta kemampuan komunikasinya tergolong rendah. Pola asuh otoriter ini menimbulkan akibat hilangnya kebebasan pada anak, inisiatif dan aktifitasnya menjadi kurang, sering membengkang pada orang tua dan cenderung tidak lagi menghargai orang yang lebih tua. Namun pada penelitian-penelitian sebelumya yang sudah di lakukan oleh beberapa peneliti ada yang berpendapat bahwa, pola asuh otoriter juga berdampak positif terhadap perilaku moral anak, seperti: anak rajin ibadah dan sopan serta taat kepada orang tua.

Meskipun pola asuh otoriter memiliki dampak negatiif, tetapi pola asuh otoriter juga memiliki dampak positif pada perkembangan anak khususnya perkembangan moral anak. Karena anak usia dini membutuhkan arahan dari orang 
tua untuk bisa mengembangkan aspek moralnya sehingga pola asuh otoriter bisa diterapkan pada orang tua yang memiliki anak usia dini untuk mengembangkan aspek moralnya agar tidak terjebak pada kenakalan remaja.

Sehingga penulis menyimpulkan bahwa pola asuh otoriter juga memiliki nilai positif dalam kelompok masyarakat tertentu misalnya di Maluku Utara dengan kehidupan lingkungan dan budayah yang hampir setiap hari kita temui perilakuperilaku yang di dapatkan di lingkungan masyrakat bahwa anak-anak tidak lagi menghargai orang yang lebih tua, suka membentak orang tua, dan tidak mau melakukan sholat atau ibadah, sehingga orang tua boleh menerapkan pola asuh otoriter karena sikap otoriter yang di terapkan oleh orang tua juga bisa mengubah tatanan nilai tertentu pada anak atau pada kehidupan keluarga.

\section{DAFTAR PUSTAKA}

Brown, Carol. 2008. Developmntal Psychology. Singapure: Sage

Demayanti, Fila.2019. Pengaruh Pola Asuh Orangtua Terhadap Perilaku Sosial Anak Di Kelompok B1 TK Kemala Bhayangkari 01 Pim Staf Besusu Tengah. Artikel, Universitas Tadilako, No. Stambuk: A 41131008.

Demista. 2013. Psikologi Perkembangan Peserta Didik. Bandung: PT RemajaRosdakarya

Dewi, NPAR dan Susilawati, LKPA.2016. Hubungan Antara Kecenderungan Pola Asuh Otoriter(Authoritarian Parenting Style) Dengan Gejala Perilaku Agresif Pada Remaja.https://ojs.unud.ac.id/index.php/psikologi/article/view/25226.

Diunduh pada sabtu 11 juli 2020.

Hurlock, Elizabeth B. 1991. Psikologi Perkembangan: Suatu Pendekatan Rentang Kehidupan.Jakarta: Erlangga.

Hidayati, NI. 2014. Pola Asuh Otoriter Orang Tua, Kecerdasan Emosi, Dan Kemandiria Anak SD.https://jurnal.untagsby.ac.id/index.php/persona/article/view/364.Diunduh pada sabtu 11 juli 2020.

Hos, HJ, dan Roslan, Suharty Hj. 2016. Dampak Pola Asuh Orang Tua Terhadap Perilaku Anak.https://media.neliti.com/media/publications/245945-none-c9988725.pdf. Di unduh pada sabtu 11 juli 2020.

Hafiz El Subhan\&Almaududi A'la Abul,Peran Pola Asuh Otoriter Terhadap Kematangan Emosi Yang Dimoderatori Oleh Kesabaran

https://www.google.com/search?q=peran+pola+asuh+otoriter+terhadap+kematang an+emosi+yang+dimoderatori+oleh+kesabaran\&oq=peran+pola+asuh+otoriter+ter hadap+kematangan+emosi+yang+dimoderatori+oleh+kesabaran\&aqs=chrome..69i5 7j69i 59j69i60j69i61.2156j0j7\&sourceid=chrome\&ie=utf-8 Diunduh pada kamis 16 juli 2020.

https://indotimur.com/ternate/asik-main-play-station-21-pelajar-terjaring-razia-satpolpp-kota-ternate. Di unduh pada rabu 29 juli 220

Jannah, Husnatul. 2012. Bentuk Pola Asuh Oramgtua Dalam Menanamkan Perilaku Moral Pada Anak Usia Di Kecamatan Ampek Angkek

http://ejournal.unp.ac.id/index.php/paud/article/view/1623. Di unduh pada sabtu 11 juli 2020. 
Kustanti, R. 2014. Pengaruh Pola Asuh Otoriter Orang Tua Terhadap Konsep Diri Anak.https://scholar.google.com/scholar?um=1\&ie=UTF8\&lr\&q=related:raopSxw0ujMj5M:scholar.google.com/.Diunduh pada sabtu 11 juli 2020.

Morisson. 2016. Pendidikan Anak Usia Dini Saat Ini. Yogyakarta: Pustaka Belajar.

Rahayu dkk.2008. Hubungan Pola Asuh Orang Tua Dengan Kesehatan Mental Remaja. Jurnal Keperawatan Unpad (Nursing Jounal of Padjajarr University), 10(18)

Santrock, J. W. 2002. Life-Span Development Perkembangan Masa Hidup, Edisi ke Lima.Tej.Juda Dumanik dan Achmad Chusairi. Jakarta: Erlangg Shochib, Moh. 1998. Pola Asuh Orang Tua. Rineka Cipta: Jakarta.

Situmorang Zulida Nina, Ismail Namira, Muarifah Alif, Wahyudi Urio, Kenakalan Remaja Dilihat Dari Pola Asuh Permisif Orangtua dan Kontrol Diri Siswa SMU di Kota Ternate.http://www.appptma.org/wp-content/uploads/2019/07/11.978-602 50710-9-6.pdf Di unduh pada rabu 29 juli 2020.

Yusuf, Syamsu. LN. (2011). Psikologi Perkembangan Anak dan Remaja. Bandung: PT Remaja Rosdakarya.

Yuliyanti, Yupit. 2017. Pola Asuh Orang Tua Dalam Membentuk Perilaku Moral Pada Anak Remaja.https://media.neliti.com/media/publications/129097-ID-pola-asuhorangtua-dalam-membentuk-peril.pdf. Diunduh pada jumat 10 juli 2020. 